DOI: https://doi.org/10.32839/2304-5809/2021-5-93-28

удК 336.02

Пухальський В.В.

Хмельницький національний університет

\title{
ГОРИЗОНТАЛЬНИЙ ПОДАТКОВИЙ МОНІТОРИНГ ЯК НАПРЯМ УДОСКОНАЛЕННЯ ПОДАТКОВОГО КОНТРОЛЮ
}

\begin{abstract}
Анотація. Однією із основних фрункцій податків, як економічної категорії є контрольна фрункція, яка реалізуеться через різні форми податкового контролю, визначені Податковим кодексом України. Однак в умовах цифрової економіки впровадження інформаційних технологій стає одним із фракторів, який забезпечує високу швидкість прийняття управлінських рішень, що в свою чергу вимагає миттевого отримання і аналізу інформації. Все більше платників податків подають податкову звітність в електронному вигляді, ведуть реєстр податкових накладних, а органи податкової служби запроваджують електронні сервіси для платників податків. Обмін документами (інформацією) в електронному вигляді також сприяе подальшій трансформації як моделі ведення бізнесу і бізнес-процесів організацій, так і традиційної концепщії податкового контролю. У цьому контексті така форма податкового контролю, як горизонтальний податковий моніторинг, стала новим інструментом - цифровим майбутнім податкового контролю. Предметом дослідження становлять теоретичні аспекти «горизонтального моніторингу», «податкового моніторингу», які викладені в зарубіжній та вітчизняній практиці. Метою даної роботи є дослідження сутності, мети, завдань, нормативного регулювання горизонтального податкового моніторингу, визначення місця, ролі, поточного стану, проблем та перспектив подальшого фрункціонування цієї форми податкового контролю в системі податкового контролю України. У статті проведено аналіз зарубіжного досвіду застосування даної форми податкового контролю, обгрунтовано та наведено авторське визначення поняття «горизонтальний податковий моніторинг», визначено мету, принципи, правові аспекти його функціонування.
\end{abstract}

Ключові слова: податковий контроль; податкові перевірки, онлайн-взаємовідносини, моніторинг, горизонтальний моніторинг, податковий моніторинг.

Puhalskyi Vadym

Khmelnitsky National University

\section{HORIZONTAL TAX MONITORING AS A DIRECTION OF IMPROVING TAX CONTROL}

Summary. One of the main functions of taxes as an economic category is the control function, which is implemented through various forms of tax control, defined by the Tax Code of Ukraine. However, in the digital economy, the introduction of information technology is becoming one of the factors that ensures high speed management decisions, which in turn requires instant receipt and analysis of information from all possible sources. More and more taxpayers file tax returns electronically, maintain a register of tax invoices, and tax authorities are introducing electronic services for taxpayers. The exchange of documents (information) in electronic form also contributes to the further transformation of both the business model and business processes of organizations, and the traditional concept of tax control. In this context, such a form of tax control as horizontal tax monitoring has become a new tool - the digital future of tax control. The subject of research is the theoretical aspects of "horizontal monitoring", "tax monitoring", which are set out in foreign and domestic practice. The object of the study is the relationship between the controlling tax authorities and taxpayers in the implementation of control measures. The purpose of this study is to clarify the nature, purpose, objectives, regulations of horizontal tax monitoring, determine the place, role, current status, problems and prospects for further functioning of this form of tax control in the tax control system of Ukraine. The article analyzes the foreign experience of this form of tax control, substantiates and presents the author's definition of "horizontal tax monitoring", defines the purpose, principles, legal aspects of its operation. The advantages of using horizontal tax monitoring for tax control bodies and taxpayers are systematized, as well as the disadvantages of such an innovation are highlighted.

Keywords: tax control; tax audits, online relationship between tax authorities and tax payers, monitoring, horizontal monitoring, tax monitoring. $\prod$ остановка проблеми. Рівень мобілізазалежить не тільки від ефективності контролю, що проводиться податковими органами відносно суб’ектів господарювання, але і ряду інших чинників у тому числі від процесу вдосконалення форм, методів та способів проведення контрольних процедур. Вирішальну роль у податковому контролі відіграють податкові перевірки (камеральні, планові виїзні, позапланові). Саме ці контрольні заходи відображають фіскальну сутність податкового контролю, націлені на формування бюджетів усіх рівнів та спонукають платників податків до сплати ними податків і зборів.
Однак, домінування влади не завжди характеризуеться економічною віддачею. Тиск на платників податків, зменшення ділової активності суб'єктів господарювання, особливо це характерно для 2020-2021 рр., коли вируе пандемія в Україні та світі, бажання обійти податкове законодавство або взагалі перейти працювати в тінь, на перше місце висувається вимога добровільної співпраці платників податків з податковими органами. Крім того, цифрова економіка, запровадження індормаційних технологій в систему податкового контролю в Україні сприяе тому, що ряд суб'єктів господарювання можуть перейти на онлайн-взаємовідносини з податковими органами, що приведе 
до зменшення податкових перевірок та економії бюджетних коштів, покращить взаємовідносини між податковими органами та бізнесом. Обмін документами (інформацією) в електронному вигляді сприяє подалышій трансформації як моделі ведення бізнесу і бізнес-процесів суб’єктів господарювання, так і традиційної концепції податкового контролю. У зв'язку з цим на даний час необхідно на законодавчому рівні запровадити альтернативні, нові форми контролю, які б в корені змінили моделі взаємовідносин між платниками податків та податковими органами. Однією iз фрорм податкового контролю, яка грунтуеться на принципі партнерства між платниками податків і податковими органами є горизонтальний податковий моніторинг.

Аналіз останніх досліджень і публікацій. Горизонтальний податковий моніторинг розглядається в сучасній науковій думщі багатьма вітчизняними та зарубіжними науковцями і практиками: C.I. Лекарь, B.I. Теремецький, С.C. Брехов, Т.О. Скоромцева, М.О. Мінаєва, С. Пелих, Т. Демків, А. Масс. Незважаючи на доробок науковців потребує уточнення поняття «горизонтальний податковий моніторинг», як прогресивна фрорма податкового контролю, поряд з цим необхідно окреслити його мету, завдання, визначити поточний стан, проблеми та перспективи застосування цієї форми податкового контролю в Україні.

Мета і завдання дослідження. Метою даної роботи є дослідження сутності, мети, завдань, нормативного регулювання горизонтального податкового моніторингу, визначення місця, ролі, поточного стану, проблем та перспектив подальшого фрункціонування ціеї форми податкового контролю в системі податкового контролю України.

Виклад основного матеріалу. Горизонтальний податковий моніторинг - це нова фрорма податкового контролю, яка передбачає надання платником податків прямого доступу податковому органу до своїх облікових систем в обмін звільнення від традиційних контрольних заходів.

Перш ніж розкривати суть, основні завдання, мету, фрункції, аспекти фрункціонування горизонтального податкового моніторингу доречно розглянути зміст поняття «моніторинг». Дедініція «моніторинг» - досить популярна та широко вживається у сучасному лексиконі. Термін «моніторинг» походить від monitor (лат. - попереджуючий) та monitoring (від англ. - контроль, відсте- ження). Для більш детального аналізу поняття «моніторинг» звернемося до довідкових та енциклопедичних видань (табл. 1).

В результаті аналізу трактувань поняття «моніторинг» у довідкових та енциклопедичних виданнях можна резюмувати, що в них визначено загальні складові моніторингу: безперервне, ретельне, постійне спостереження, контроль, аналіз, відповідність бажаному результату, прогнозування, запобігання. Врахування вищезазначених складових моніторингу при формулюванні поняття "моніторинг» забезпечить, на нашу думку, комплексне та об'єктивне визначення змісту поняття «податковий моніторинг».

У економічній літературі та практиці податкового контролю в зарубіжних країнах застосовуеться термін не податковий моніторинг, а «горизонтальний моніторинг». В сучасному світі «горизонтальний моніторинг» кваліфрікують, як один із видів альтернативних способів попередження та розв'язання податкових спорів Alternative dispute resolution (ADR), який застосовуеться вже близько у 30 країн світу (Нідерланди, Ісландія, Норвегія, Німеччина, Словенія, Італія, Іспанія, Португалія, Франція, Великобританія, Данія, Канада, США, ЮАР, Австралія, Нова Зеландія та ін.). Перехід на такий підхід грунтуеться на принципах довіри, прозорості та взаємовигідної співпраці.

Вперше механізм «горизонтального моніторингу» (Horizontal Monitoring Program) був запроваджений в 2005 р. у Нідерландах з урахуванням рекомендацій Наукової ради з державної політики (Scientific Council for Government Policy): взаємовідносини платників податків i держави необхідно будувати на основі принципів взаємного співробітництва та прозорості бізнес-процесів, де держава приймає на себе відповідальність за податковий комплекс, а також стимулюе розвиток саморегулювання і самоконтролю з боку учасників податкових відносин [6]. Чому автори проекту Нідерландів застосували термін «горизонтальний моніторинг»? Відповідь криеться у тому, що вони хотіли показати принципову відмінність від класичної форми вертикального контролю.

Наступною країною після Нідерландів була Ірландія, яка у вересні 2005 р. запровадила спільну програму податкової служби країни і великих корпорацій під назвою «Cooperative Compliance

\section{Трактування поняття «моніторинг» у довідкових та енциклопедичних виданнях}

\begin{tabular}{|c|l|}
\hline Джерело & \multicolumn{1}{|c|}{ Визначення поняття «моніторинг» } \\
\hline $\begin{array}{c}\text { Великий тлумачний словник } \\
\text { сучасної української мови } \\
\text { (укладач В. Бусел) }\end{array}$ & $\begin{array}{l}\text { Безперервне стеження за будь-яким процесом з метою виявлення його } \\
\text { відповідності бажаному результату. }\end{array}$ \\
\hline $\begin{array}{c}\text { Сучасний економічний } \\
\text { словник }\end{array}$ & $\begin{array}{l}\text { Неперервне спостереження за економічними об’ектами, аналіз їх діяльності } \\
\text { як складової управління }\end{array}$ \\
\hline $\begin{array}{c}\text { Нокладач Б. Райзберг) } \\
\text { украйнської мови } \\
\text { (укладач І. Радченко) }\end{array}$ & $\begin{array}{l}\text { Система спостереження і контролю за станом перебігу якого-небудь процесу } \\
\text { з метою виявлення його відповідності бажаному результату, встановленим } \\
\text { нормам, параметрам тощо }\end{array}$ \\
\hline $\begin{array}{c}\text { Тлумачний словник } \\
\text { української мови } \\
\text { (укладач В. Федоров) }\end{array}$ & $\begin{array}{l}\text { Безперервне стеження за яким-небудь процесом з метою виявлення його } \\
\text { відповідності бажаному результату, а також прогнозування та запобігання } \\
\text { критичним ситуаціям }\end{array}$ \\
\hline Оксрордський словник & Ретельне спостереження, контроль за роботою \\
\hline
\end{tabular}


program». Ірландські податківці напращювали важливий принцип, пов'язаний з горизонтальним моніторингом, а саме: приеднання до системи не повинно означати, що у компанії в минулому були будь-які проблеми із нарахування і сплатою податків, так само, як і вихід із цієї системи не буде означати, що виникли податкові проблеми. Суттевим є те, що податкові органи за допомогою горизонтального моніторингу впевнюються у тому, що будь-яке рішення менеджменту компанії продиктовано її бізнес-інтересами, а не спробою податкової оптимізації [7].

Цікавим $є$ досвід у застосуванні горизонтального моніторингу в США, де діе програма укладення угоди між податковим органом i платником податків до подачі податкової звітності («Pre-Filing Agreement Program») та програма створення гарантій дотримання законодавства «Compliance Assurance Process», згідно якої платники податків разом із Службою Внутрішніх Доходів виявляють потенційні податкові ризики до подачі податкової звітності.

У Республіці Казахстан на законодавчому рівні (р. 15, ст. 129-133 Податкового кодексу) запроваджено податковий моніторинг. Податковий моніторинг у цій країні здійснюеться шляхом аналізу фінансово-господарської діяльності платників податків 3 метою визначення їх реальної оподаткованої бази, контролю за дотриманням податкового законодавства Республіки Казахстан і застосованих ринкових цін з метою здійснення контролю при трансфертному ціноутворенні. Податковий моніторинг складається 3 моніторингу великих платників податків та горизонтального моніторингу. У свою чергу горизонтальний моніторинг передбачає обмін інформацією і документами між уповноваженим органом і платником податків, який грунтується на принципах співробітництва, законності, прозорості та обгрунтованої довіри [8].

У Податковому кодексі Республіки Узбекистан (р. 19 Податковий моніторинг, ст. 169-174) на законодавчому рівні затверджено механізм дії податковому моніторингу [9]. Відповідно до Податкового кодексу Кабінет Міністрів Узбекистану прийняв постанову від 20.11.2020 p. № 736 «Про додаткові заходи щодо подальшого удосконалення податкового адміністрування», якою затвержено Положення про порядок проведення податкового моніторингу. Відповідно до положення, предметом податкового моніторингу $є$ дотримання податкового законодавства, правильності нарахування, повноти і своєчасності сплати (перерахування) податків і зборів юридичною особою, по відношенню до якої проводиться податковий моніторинг.

Свої перші кроки у цьому напряму робить і Україна, коли ст. 62.1.4 ПКУ визначила, що одним із способів податкового контролю $€$ моніторинг контрольованих операцій [10], а 06.10.2015 р. набув чинності наказ Міністерства фрінансів України від 14.08.2015 р. № 706 «Про затвердження Порядку проведення моніторингу контрольованих операцій та Порядку опитування уповноважених, посадових осіб та/або працівників платника податків 3 питань трансорертного ціноутворення» [11]. 3 28.04.2011 р. в Україні в якості експерименту розпочалося запроваджен- ня горизонтального моніторингу. Наступною за моніторингом контрольованих операцій з 2017 р. успішно почала діяти система автоматизованого моніторингу податкових накладних / розрахунків коригування критеріям оцінки ступеня ризиків. Тим самим Державна податкова служба України захищає економічні інтереси держави та сумлінних платників податків від мінімізаційних схем та зловживань.

На офіційному сайті ДФС (ДПС) України знаходимо таке визначення «горизонтального моніторингу». Горизонтальний моніторинг - це здійснення процедури відстеження та аналізу органом державної податкової служби податкових ризиків, проведених і запланованих великим платником податків фрінансово-господарських операцій [12].

Наведені вище різні трактування «горизонтальний моніторинг», «податковий моніторинг» свідчать, про неоднозначність цих термінів. На нашу думку, необхідно розглядати термін «горизонтальний податковий моніторинг». Чому? Відповідь криеться у змісті терміну «горизонтальний податковий моніторинг». У загальному сенсі під моніторингом розуміють діяльність спостереження (слідкування) за певними об'єктами або явищами. Розрізняють два типи взаємозв'язку елементів економічної системи: вертикальні та горизонтальні. Горизонтальні зв'язки є партнерськими, добровільними, конкурентними. У соціально-орієнтованих економічних системах домінують саме партнерські взаємини. I третє уточнення, де саме мають діяти ці горизонтальні зв'язки економічної системи? I тут потрібно конкретизувати, що саме підпадає під горизонтальний податковий моніторинг - правильність нарахування, своєчасної сплати податків та правильність і законність ведення юридичними особами податкової документації.

На даний час в Україні відсутне законодавче регулювання горизонтального податкового моніторингу, а звідси не визначена сама дефініція, мета, принципи, критерії його оцінки, порядок розкриття даних бухгалтерського i податкового обліку, роль системи внутрішнього контролю у цьому процесі.

На нашу думку, горизонтальний податковий моніторинг - це фрорма добровільного податного контролю, яка націлена на розширений обмін інформацією між податковими органами та платниками податків; підвищення, прозорості й ефрективності контрольних процедур і заходів щодо інформаційного масиву по всіх податках i зборах, які сплачують платники податків; ефективний засіб попередження податкових спорів.

Мета горизонтального податкового моніторингу полягає у контролі за дотриманням норм ПКУ та інших нормативних актів у сфрері податків і зборів, за правильністю нарахування та своєчасністю сплати податків і зборів, а також правильності ведення обліку у платників податків. Горизонтальний податковий моніторинг вигідний для обох сторін учасників горизонтального податкового моніторингу. Під час проведення горизонтального податкового моніторингу податкові органи мають на меті:

- оперативно і якісно здійснювати фрункції 3 контролю і нагляду за дотриманням законо- 
давства про податки і збори, за правильністю обчислення, повнотою і своєчасністю внесення до відповідного бюджету податків і зборів;

- податковий моніторинг дозволить підвищити прогнозованість надходжень податків до всіх рівнів бюджетної системи України, та своєчасно виявляти прогалини і колізії в податковому законодавстві;

- впровадження податкового моніторингу на постійній основі буде сприяти скороченню витрат на проведення податкових перевірок, судових витрат у зв'язку зі скороченням податкових суперечок і підвищенню рівня правової культури платників податків по сплаті податків.

Для платників податків - учасників процедури податкового моніторингу перевага такої участі полягає в тому, що за період, щодо якого здійснюеться податковий моніторинг, платник податків має можливість оперативно дізнаватися позицію податкового органу щодо оподаткування окремих операцій та угод і не піддаватися виїзним і камеральних податкових перевірок за зазначені періоди у наступному.

Для платників податків, крім вигоди від запровадження горизонтального податкового моніторингу, мають місце і недоліки, а саме: постійний контроль з боку податкового органу, ризик витоку конфріденційної інфрормації та підвищені вимоги до системи внутрішнього контролю.

Серед принципів горизонтального податкового моніторингу доречно виділити наступні: добровільності, взаємної співпраці, відкритості і прозорості, звільнення від вертикальних перевірок, оперативного вирішення спорів у форматі «мотивованої думки», звільнення від сплати штрафрних санкцій (рис. 1).

Принцип добровільності означає, що контроль в режимі горизонтального податкового моніторингу проводиться не 3 ініціативи податкового органу, а за бажанням платника податків, на підставі поданої ним заяви. При певних обставинах можливе припинення проведення податкового моніторингу достроково. Принцип взаємної співпраці необхідно розглядати у контексті партнерства між обома сторонами. Принщип відкритості і прозорості у горизонтальному податковому моніторингу полягає у наданні суб’ектами господарювання податковим органам доступ до своєї інформаційної системи, за допомогою якої ведеться податковий і бухгалтерський облік. Одночасно важливо упередити витік інформації з боку податкових органів про діяльність платника податків.

Документообіг між органом податкового контролю та платником податків необхідно здійснювати у електронному вигляді, тобто учасник горизонтального податкового моніторингу має вести облік у автоматизованому режимі. Платник податків може надати податкову органу віддалений доступ до своєї системи чи шляхом обміну інформацією через спеціалізованого оператора електронного документообігу.

Система внутрішнього контролю суб'єкта господарювання включає п'ять компонентів, у т. ч. контрольне середовище; система виявлення і оцінки ризиків; контрольні процедури; а також інформаційні системи, в яких дані процедури реалізовані; система оцінки едективності та моніторингу результатів внутрішнього контролю. Кожен структурний компонент є невід'ємною складовою системи внутрішнього контролю і забезпечуе едективність іï фрункціонування. Для кожного з компонентів передбачені вимоги щодо розкриття інформації.

В основу системи внутрішнього контролю покладено виявлення та оцінки ризиків, пов'язаних 3 бізнес-процесами суб'єкта господарювання. Розкриття інформації про рівень ризику дозволяє податковому органу провести аналіз якісних і кількісних аспектів виявлених ризиків і дати оцінку схильності суб'єкта господарювання до здійснення ризикових операцій, ведення бізнесу, пов'язаного з ризиковими сегментами економіки, консервативності або агресивності стратегії, що використовуеться в управлінні ризиками. Розкриття інфрормації про ризики здійснюеться на основі принципу суттєвості. Система внутрішнього контрою добре досліджена у аудиті.

Таким чином, в сучасних умовах - умовах цифррової трансформації традиційні форми взаємовідносин між податковими органами та платниками податків дещо застарілі та потребують удосконалення. На нашу думку, горизонтальний податковий моніторинг - це нова, прогресивна форма податкового контролю, яка реалізується у онлайн-фрорматі на основі віддаленого доступу до цифррових даних обліку і звітності платника податків.

\begin{tabular}{|c|}
\hline Принципи горизонтального податкового моніторингу \\
\hline Добровільності \\
\hline Взаємної співпраці \\
\hline Відкритості і прозорості \\
\hline Звільнення від вертикальних перевірок \\
\hline Оперативного вирішення спорів у форматі «мотивованої думки» \\
\hline Звільнення від сплати штрафних санкцій \\
\hline
\end{tabular}

Рис. 1. Принципи горизонтального податкового моніторингу 
Висновки. Проведене дослідження дае можливість сформулювати наступні висновки. Горизонтальний податковий моніторинг - перспективна форма податкового контролю, яка передбачає перехід від традиційних форм податкового контролю, таких як камеральні та виїзні планові, позапланові перевірки, до розширеної інформаційної взаємодії, що передбачає доступ до даних платника податків в режимі реального часу.

Така форма контролю має переваги та недоліки, а саме: скорочення обсягу подання паперових документів; скорочення кількості ведення операцій вручну; підвищення достовірності даних обліку і звітності; дистанщійна форма спілкування з податковими органами тощо. Крім того, режим горизонтального податкового моніторингу істотно прискорюе вирішення спірних ситуацій щодо застосування податкового законодавства та дозволяе платнику податків уникнути в майбутньому донарахування сум податків, пені та штрафів, а також знижуе тягар податкового контролю.

До недоліків можна віднести наступні: додаткові витрати у суб’ектів бізнесу на технічні засоби, потреба у висококваліфікованих кадрах, які могли б працювати в інформаційному середовищі, запровадження системи внутрішнього контролю, збереження конфіденщійності інформації та ін.
В світовій практиці домінують горизонтальні податкові відносини між державою та платниками податків. В Україні високий рівень корупщії та відсутне законодавче закріплення ціеї форми податкового контролю не сприяють успішній трансформації традиційних фрорм податкового контролю в горизонтальну площину.

Для запровадження в практику органів податкової служби України горизонтального податкового моніторингу потрібно розробити та затвердити на законодавчому рівні концепцію горизонтального податкового моніторингу, яка б включала понятійний апарат; критерії відбору учасників горизонтального податкового моніторингу; перелік документів, які подаються для участі у моніторингу; форми і формати документів, які є підставою для проведення моніторингу, вимоги до розкриття показників податкового обліку, способи інформаційної взаємодії між податковим органом та платником податків а також розробку стандартного файлу податкового аудиту для автоматичної перевірки даних обліку і звітності та ін. За цих умов податковий моніторинг забезпечить якісно новий рівень реалізації податкового контролю, нащілений на побудову довірчих відносин між платниками податків і державою.

\section{Список літератури:}

1. Великий тлумачний словник сучасної української мови / [уклад. і голов. ред. В. Т. Бусел]. Київ : Ірпінь : ВТФ «Перун», 2001. 1440 с.

2. Райзберг Б.А. Современный экономический словарь. Москва : ИНФРА-М, 2003. 480 с.

3. Новий тлумачний словник української мови / [уклад. I. Радченко]. Кам'янець-Подільський : Абетка, 2006. $544 \mathrm{c.}$

4. Тлумачний словник української мови / В. Федоров. Львів, 2010. URL: http://eslovnik.com/ (дата звернення: 09.05.2021).

5. Оксфордський словник / Дж. Борн. Лондон, 2005. URL: http://www.oed.com/ (дата звернення: 09.05.2021).

6. Мaac A. Горизонтальный мониторинг: изменения в системе налогообложения Нидерландов. URL: https://palata-nk.ru/global/global-experience/gorizontalnyy-monitoring-izmeneniya-v-sisteme-nalogooblozheniyaniderlandov/ (дата звернення: 11.05.2021).

7. Organization for economic cooperation and development. Forum on Tax Administration (FTA). URL: www/oecd/org/ (дата звернення: 11.05.2021).

8. Кодекс Республики Казахстан О налогах и других обязательных платежах в бюджет. URL: https://online.zakon.kz/ document/?doc_id=36148637\#pos=4;-106 (дата звернення: 11.05.2021).

9. Податковий кодекс Республіки Узбекистан (нова редакція). URL: https://www.bss.uz/nalogoviy-kodeks-2020uzbekistan (дата звернення: 11.05.2021).

10. Податковий кодекс України від 02.12.2010 p. № 2755-VI. URL: https://zakon.rada.gov.ua/laws/show/275517\#Теxt (дата звернення: 12.05.2021).

11. Про затвердження Порядку проведення моніторингу контрольованих операцій та Порядку опитування уповноважених, посадових осіб та/або працівників платника податків з питань трансфертного ціноутворення : наказ Міністерства фінансів України від 14.08.2015 № 706. URL: https://zakon.rada.gov.ua/laws/show/z105515\#Техt (дата звернення: 12.05.2021).

12. Горизонтальний моніторинг як новий сервіс для сумлінних платників податків / ДФС України : Офіційний портал. URL: http://sfs.gov.ua/arhiv/modernizatsiya-dps-ukraini/povidomlenia_/2012_povidomleniamodernizatsia/print-59282.html\#: :text (дата звернення: 12.05.2021).

\section{References:}

1. Large explanatory dictionary of the modern Ukrainian language (2001) / [ed. and heads. ed. W. T. Busel]. Kyiv: Irpin: PH "Perun", 1440 p.

2. Reisberg B.A. (2003) Modern economic dictionary. Moscow: INFRA-M, $480 \mathrm{p}$

3. New explanatory dictionary of the Ukrainian language (2006) / [ed. I. Radchenko]. Kamyanets-Podilsky: Abetka, 544 p.

4. Explanatory dictionary of the Ukrainian language (2010) / V. Fedorov. Lviv. Available at: http://eslovnik.com/ (accessed 9 May 2021).

5. Oxford Dictionary / J. Bourne. London, 2005. Available at: http://www.oed.com/ (accessed 9 May 2021).

6. Maas A. Horizontal monitoring: changes in the system of taxation of the Netherlands. Available at: https://palata-nk.ru/global/global-experience/gorizontalnyy-monitoring-izmeneniya-v-sisteme-nalogooblozheniyaniderlandov/ (accessed 11 May 2021).

7. Organization for economic cooperation and development. Forum on Tax Administration (FTA). Available at: www/oecd/org/ (accessed 11 May 2021).

8. Code of the Republic of Kazakhstan on taxes and other mandatory payments to the budget. Available at: https://online.zakon.kz/document/?doc_id=36148637\#pos=4; - 106 (accessed 11 May 2021). 
9. Tax Code of the Republic of Uzbekistan (new edition). Available at: https://www.bss.uz/nalogoviy-kodeks-2020uzbekistan (accessed 11 May 2021).

10. Tax Code of Ukraine dated 02.12.2010 № 2755-VI. Available at: https://zakon.rada.gov.ua/laws/show/275517\#Text (accessed 12 May 2021).

11. On approval of the Procedure for monitoring controlled transactions and the Procedure for interviewing authorized, officials and/or employees of the taxpayer on transfer pricing: order of the Ministry of Finance of Ukraine dated 14.08.2015 № 706. Available at: https://zakon.rada.gov.ua/laws/show/z1055-15\#Text (accessed 12 May 2021).

12. Horizontal monitoring as a new service for conscientious taxpayers / SFS of Ukraine Official portal. Available at: http://sfs.gov.ua/arhiv/modernizatsiya-dps-ukraini/povidomlenia_/2012_povidomlenia-modernizatsia/print59282.html\#: :text (accessed 12 May 2021). 